\title{
Development E-Module of Customary Forest Kantuk Based on Android to Improve Self Regulated Learning of Biology Education Students
}

\author{
Arif Supriyadi ${ }^{1}$, I Gusti Putu Suryadarma ${ }^{2}$ \\ \{Arifsupriyadilive@gmail.com ${ }^{1}$, samodhaya@yahoo.com ${ }^{2}$ \} \\ 1,2Universitas Negeri Yogyakarta , Jl. Colombo No.1, Karang Malang, Caturtunggal, Kec. Depok, \\ Kab. Sleman, Daerah Istimewa Yogyakarta, Indonesia 55281
}

\begin{abstract}
This study aims to: (1) produce customary forest ecology modules that are appropriate for environmental knowledge courses, (2) produce effective customary forest ecology modules to improve students' self regulated learning. Based on Research and Development, the stages of development of ADDIE, (Analysis), (Design), (Development), (Implementation) and (Evaluation). The study was conducted at Tanjungpura University Biology Education. Subject research 25 student at research classes and 29 student at experimental class. Data collection techniques used product feasibility assessment sheets, observation self regulated learning. Hypothesis testing in this study using U Mann Whitney test. The results of the study (1) e-module is suitable for Untan biology education students, (2) e-module effectively enhances of self regulated learning of Untan biology students.
\end{abstract}

Keywords: Conceptal understanding, customary forest, e-module, self regulated learning

\section{Introduction}

The serious thing that is the responsibility of education today is human dependence on digital gadgets both among children, adolescents and adults at the age of education, even becoming addicted for its users. The next thing to be raised in this research is the attention of students to the surrounding environment, the current urgency that is the main topic is deforestation, conversion of forests and the wisdom of indigenous peoples to protect customary forests, the selection and use of learning resources that affect the lecture process, whether conducted in the room (in door) or activities outside the field (out door). In the emodule that is created, the contents are related to the definitions, examples and phenomena of the customary forest. 


\subsection{Education Tripusat}

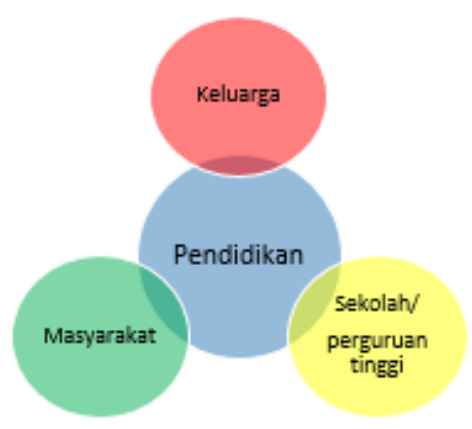

Fig 1. Education Tripusat

The education tripusat referred to herein is the educational environment including "education in the family environment, education in the school environment, and education in the community / youth environment [1].

\subsection{Teaching materials}

According to [2] teaching materials are all forms of material used to assist teachers in carrying out teaching and learning activities.

\subsection{Module}

Modules are teaching materials that are designed systematically based on a particular curriculum and are packaged in the smallest unit of study and allow learning independently in a certain time [3]. Modules are one form of teaching material that is packaged in a whole and systematic manner, in which contains a set of learning experiences that are planned and designed to help students master specific learning goals [4].

A good module has several characteristics.
1) Self Instructional
2) Self contained
3) Stand alone
4) Adaptive
5) User friendly [5]

\subsection{Self regulated learning}

According to [6] Masrun, et al (1986: 8), independence is an attitude that allows a person to act freely, do something on his own impulse and for his own needs without help from others, or think and act original creative and full of initiative, able affect the environment, have confidence and get satisfaction from his business. Zimmerman (2015: 541) explained in general that self-regulated learning is described through levels or degrees which include activeness both in meta cognition, motivation, and student behavior in the learning process. The terms related to learning independence include self regulated learning [7]. According to Hargis (2000) defines learning independence as self-regulated learning, namely efforts to deepen and manipulate associative networks in a particular field, and monitor and improve the 
process of deepening concerned [8] (http://www.jhargis.com).

\subsection{Ecology}

Ecology adheres to the principle of balance and harmony of all natural components. This as stated by [9] said, "The paradigm of solving environmental problems and forest destruction should be directed more deeply and integrated in the ethics of life. The community has a commitment to maintain and preserve the environment as a life support system."

\subsection{Customary forest}

The learning process in higher institutions also needs to refer to local potential and be adapted to the characteristics of students (prospective teacher students). Local potential is an event, problem, or phenomenon that occurs in the student's home environment [10] Customary forests have become one of the important assets for indigenous people to guarantee their welfare, but the State has denied the existence [11]

\section{Method}

\subsection{Type of research}

This research produced teaching materials in the form of e-modules for the enrichment of traditional forest ecology materials and then tested the effectiveness of these products. The development model used is the ADDIE development model. There are five stages in the ADDIE model, namely: (Analysis, Design, Development, Implementation and Evaluation), in accordance with the stages of design and development [12].

\subsection{Development procedures}

a. Analysis phase.

At this stage an analysis of information related to competence, students and instructors is carried out.

b. Design phase (design)

At this stage the e-module is designed to be made according to the lecture material.

c. Development phase (development)

At this stage a more specific development is carried out, including: pre-preparation, compilation, editing and revision.

d. Implementation phase (implement)

At this stage, product development is implemented in research in the field.

e. Evaluation stage

At this stage, product development is evaluated whether it is feasible or not.

\subsection{Research design}

The method used is a quasi-experimental research design, what is used only posttest control group design. In the experimental class was given treatment and posttest then the results were compared with the control class posttest without treatment. 
In the experimental class the treatment given was using the ecology module of the customary forest.

\subsection{Data collection techniques}

The technique used to collect data is as follows:

a. Descriptive data came from material expert lecturers, media expert lecturers, supporting lecturers and students in the form of criticisms and suggestions, feasibility validation sheets.

b. The e-module feasibility data comes from material expert lecturers, media expert lecturers and supporting lecturers, then student responses through questionnaires.

c. self regulated learning data using questionnaire sheets and observation sheets. [13]

\subsection{Data collection instruments}

The instruments used to collect data are as follows:

\section{E-module eligibility questionnaire}

The questionnaire used in this study was used to determine the feasibility of the ecology enrichment e-module of customary forests including aspects of content eligibility, presentation feasibility, language, graphics and construction with a scale of 4 namely: very good (4), good (3), less (2), very lacking (1).

\section{Questionnaire for self regulated learning}

The questionnaire used in this study was used to determine self regulated learning including 6 indicators which were translated into 20 items with positive statements and negative statements.

Table 1 . Scoring Criteria for self regulated learning Questionnaire

\begin{tabular}{llll}
\hline Positif Statement & Score & Negatif Statemenet & Score \\
\hline Strongly agree & 5 & Strongly agree & 1 \\
Agree & 4 & Agree & 2 \\
Less agree & 3 & Less agree & 3 \\
Disagree & 2 & Disagree & 4 \\
Strongly disagree & 1 & Strongly disagree & 5 \\
\hline
\end{tabular}

\subsection{Data analysis techniques}

The assessment instruments are validated to get valid data. An instrument is said to be valid if the instrument used can measure what is to be measured [14]. The validity of the instruments used in this study was the content validity and construct. The content validity and construct validity were carried out using an expert judgment approach, the researcher consulted and received input from the validator lecturer to determine whether the assessment instrument was feasible or not.

1) Analysis of the feasibility instrument of the enrichment e-module

Validation of the customary forest ecology e-module was carried out to material experts, instructional media experts, supporting lecturers and peer reviewers. The data obtained in the form of qualitative data and quantitative data. 
Tabel 2. feasibility of enrichment e-module

\begin{tabular}{cc}
\hline Final score & Criteria \\
\hline $\mathbf{3}, \mathbf{2 5}-\mathbf{4 , 0 0}$ & Verry good \\
$\mathbf{> 2 , 5 0 - 3 , 2 5}$ & Good \\
$\mathbf{> 1 , 7 5 - 2 , 5 0}$ & Enough \\
$\mathbf{1 , 0 0 - 1 , 7 5}$ & Less \\
\hline
\end{tabular}

\section{2) Analysis of test instruments}

To analyze the results of the concept understanding test in this study, two types of statistics are used, namely descriptive statistics and inferential statistics.

Because self regulated learning data is obtained by questionnaire then the data is ordinal, then compiled with a Likert scale so that the data is discrete, the data is automatically analyzed using nonparametric international statistics. Therefore the self regulated learning hypothesis is calculated using the U Mann Whitney test.

\section{Result}

\subsection{Result of product development}

Table 3. Assessment table of material experts

\begin{tabular}{clcc}
\hline No & \multicolumn{1}{c}{ Aspect } & Score & Criteria \\
\hline $\mathbf{1}$ & Material enrichment & 3,40 & Very good \\
$\mathbf{2}$ & Material serving & 3,38 & Very good \\
$\mathbf{3}$ & Language & 3,00 & Good \\
& Mean & 3,26 & Very good \\
\hline
\end{tabular}

Table 4. Assessment table of media experts

\begin{tabular}{clcc}
\hline No & Aspect & Score & Criteria \\
\hline $\mathbf{1}$ & Cover & 3,67 & Very good \\
$\mathbf{2}$ & Material & 3,41 & Very good \\
$\mathbf{3}$ & Construct & 3,25 & Good \\
& Mean & 3,54 & Very good \\
\hline
\end{tabular}

Table 5. Assesment of teacher

\begin{tabular}{ccccc}
\hline No & \multirow{2}{*}{ Aspek } & \multicolumn{2}{c}{ Skor } & Kriteria \\
\cline { 3 - 4 } & & D1 & D2 & \\
\hline $\mathbf{1}$ & Material & 3,4 & 3,4 & Very good \\
$\mathbf{2}$ & Construct & 3,4 & 3,4 & Very good \\
$\mathbf{3}$ & Language & 3,4 & 3,4 & Very good \\
\hline & Rata-rata & 3,3 & 3,3 & Very good \\
\hline
\end{tabular}

Based on the assessment table of material experts, media experts and instructors, the results of the e-module assessment of customary forest ecology meet the criteria. Material expert assessment is based on aspects of feasibility, presentation and language with a very good category assessment. The assessment of media experts is based on aspects of cover, 
content and presentation of e-modules with very good categories. Teacher assessment based on aspects of material, construction and language with very good categories.

\subsection{Product trial results}

Based on the results of research that has been carried out e-modules have an increased effect on the self regulated learning of Untan biology education students, because self regulated learning data is obtained by questionnaire then the data are ordinal, then compiled with a Likert scale so that the data is discrete, automatically the data are analyzed using nonparametric internal statistics. Therefore the self regulated learning hypothesis is calculated using the U Mann Whitney test.

Table 6. Result of self regulated learning data

\begin{tabular}{lcc}
\hline \multicolumn{1}{c}{ Aspect } & \multicolumn{3}{c}{ Data } \\
\cline { 2 - 3 } & Experiment class & Control class \\
\hline Student & 29 & 25 \\
U Mann Whitney tesis & & 0,000 \\
Self regulated learning & Post-test & \\
Maximum & 99 & Post-test \\
Minimum & 80 & 86 \\
Average & 87,24 & 69 \\
\hline
\end{tabular}

The self regulated learning of Untan biology education students who use e-modules on environmental knowledge has a higher value compared to those who do not use e-modules. This is based on the acquisition of the value of the two classes between the experimental class that uses e-modules of environmental knowledge and the control class that does not use emodules of environmental knowledge. The acquisition value in the experimental class that uses e-module environmental knowledge is higher than the class that does not use e-module environmental knowledge. The average value of self regulated learning in the experimental class 87.24 As for the average value of self regulated learning in the control class 77.32 
Fig 2. Comparison of self regulated learning

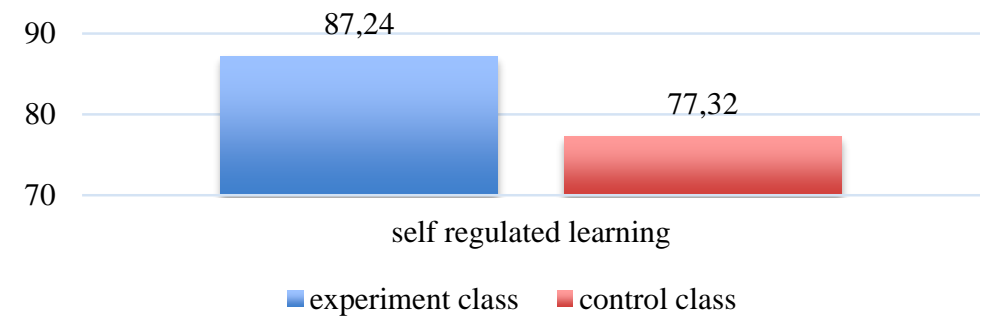

The use of e-modules is undeniably one of the effective media to see the independence of the attention in learning, as research [15]. In online learning teachers can see the attention of individual students by looking at questions which is asked by students. These questions relate to the material at the time and the material that the students have exceeded.

The use of mobile learning as well as customary forest ecology modules has a number of advantages and disadvantages as described by [16] Scoot et al. (2015: 10-13) as follows:

Table 7. Bennefit and challenge of using mobile learning

\begin{tabular}{|c|c|c|}
\hline No & Bennefit & Challenge \\
\hline 1 & Ability to learn on the go & Different acces to device and internet \\
\hline 2 & Reach underserved & Use must be monitored \\
\hline 3 & Improve higher-order thinking skill & $\begin{array}{l}\text { Prevailing attitudes and prejudice againts using } \\
\text { technology for instruction }\end{array}$ \\
\hline 4 & Support alternative learning environment & Limiting physical attributes \\
\hline 5 & Enable personalized learning & Mobile device are shared among a ground \\
\hline 6 & Motivate student & $\begin{array}{l}\text { Way in which the device are implemented } \\
\text { impact the effectiveness of them }\end{array}$ \\
\hline
\end{tabular}

\section{Aknowledgements}

An important concern is that mobile learning cannot function properly without clear learning, good delivery of material, and compatibility of the material with learning outcomes, ease of use and available resources.

\section{References}

[1] Fudyartanta, Buku Ketaman Siswaan: Yogyakarta. pp. 99 (1990).

[2] Abdul Majid. Perencanaan Pembelajaran. Bandung: PT Remaja Rosda. (2009: 173)

[3] Purwanto, dkk Pengembangan Modul. Jakarta: Depdiknas Pustekom. pp. 9 (2007)

[4] Dikmenjur, Pedoman Penulisan Modul. Jakarta: (2004).

[5] Daryanto, Menyusun Modul Bahan Ajar untuk Mempersiapkan Guru dalam Mengajar. Yogyakarta: Penerbit Gava Media. pp. 9-1 (2013).

[6] Masrun, dkk. Studi Mengenai Kemandirian pada Penduduk dari Tiga Suku Bangsa (Jawa, Batak, Bugis. Laporan Penelitian. Yogyakarta: Universitas Gajah Mada. pp.8 (1986). 
[7] Zimmerman. Self-Regulated Learning: Theories, Measures, and Outcomes. 2nd edition, Vol. 21, pp. 541. International Encyclopedia of the Social \& Behavioral Sciences, http://dx.doi.org/10.1016/B978-0-08-097086-8.26060-1 (2015).

[8] Hargis. The Self-Regulated Learner Advantage: Learning Science on the Internet. Vol.4 No.4. Electronic Journnal of Sciene Education, (Online), (http://wolfweb.unr.edu/homepage/cr owther/ ejse/hargis.html.(2000).

[9] Suryadarma Peran Hutan Masyarakat Adat dalam Menjaga Stabilitas Iklim: Satu Kajian Perspektif Deep Ecology (Kasus Masyarakat Desa Adat Tenganan, Bali). pp. 50-56. Jurnal Konservasi Flora Indonesia Dalam Mengatasi Dampak Pemanasan Global. (2008)

[10] Marlina, Pemanfaatan Lingkungan Lokal dalam Laboratorium Berbasis Inkuiri Terhadap Kerja Ilmiah Mahasiswa Calon Guru Biologi. Vol. 10 (1). pp.94. Jurnal Visi Ilmu Pendidikan.: 1052-1060.(2013).

[11] AMAN, 2018). Hutan adat. Diakses 14 agustus 2019.

[12] Richery \& Klein. Design and Development Research: Methods, Strategies, and Issues. Mahwah, NJ: Lawrence Erlbaum Associates, Publishers. pp.8. (2007)

[13] Kana hidayati dan Endang listyani, tentang pengertian dan indikator

kemandirian belajar, dalam http://id.shvoong.com/socialsciences/education/2193115pengertian-kemandirian-belajar. pp.96 (2010)

[14] Sukardi. Metodologi Penelitian Pendidikan Kompetensi dan Praktiknya. Jakarta : Bumi Aksara. pp. 121 (2013).

[15] Hermawanto dkk. Pengaruh Blended Learning terhadap Penguasaan Konsep dan Penalaran Fisika Peserta Didik Kelas X. pp. 67-76. Jurnal Pendidikan Fisika Indonesia 9 (2013).

[16] Scoot et al. Changing Education with Mobile Learning. Mobile Learning, 1-21. DOI:10.1002/9781118938942.ch1.pp.10-13 (2015) 